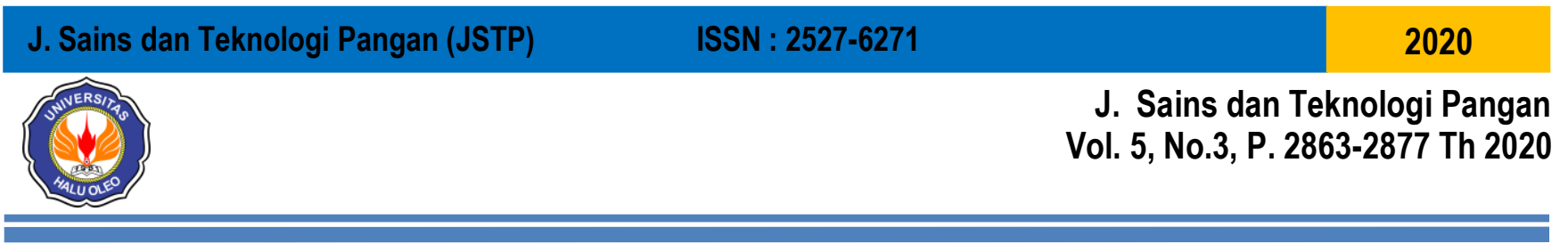

\title{
KANDUNGAN VITAMIN C DAN PREFERENSI KONSUMEN TERHADAP SELAI LEMBARAN PALA DENGAN PENAMBAHAN SARI BUAH NAGA
}

\author{
[Vitamin C Content And Consumer's Preference Of Nutmeg-Sheet Jam With The Addittion Of Dragon Fruit Juice] \\ Sophia G. Sipahelut ${ }^{1 *}$, Sri Rejeki², John Alfred Patty ${ }^{3}$ \\ 1Jurusan Teknologi Hasil Pertanian, Fakultas Pertanian,Universitas Pattimura, Ambon \\ 2Jurusan Ilmu dan Teknologi Pangan, Fakultas Pertanian, Universitas Halu Oleo, Kendari \\ 3Jurusan Budidaya Pertanian, Fakultas Pertanian, Universitas Pattimura, Ambon \\ Email : sipahelut.grace@gmail.com; Telp : 085243486353
}

Diterima tanggal 25 Mei 2020

Disetujui tanggal 28 Juni 2020

\begin{abstract}
Utilization of nutmeg flesh is still limited; thus, processing it into nutmeg-sheet jam is aimed to improve its added value. However, nutmeg flesh has astringent and bitter taste caused by the tannin level which may impact the processed products. To overcome this problem, a combination of nutmeg flesh and dragon fruit was carried out. The purpose of this study was to determine the exact proportion of nutmeg and dragon fruit juice to produce a nutmeg-sheet jam that is preferred by consumers. This study used a one-factor Randomized Complete Design, namely the proportion of nutmeg flesh juice and dragon fruit juice consisting of three treatment levels, namely: P1 (100\%:0\%), P2 (75\%:25\%), P3 (50\%:50\%). The organoleptic testing on nutmeg-sheet jam products used the hedonic test conducted by 30 semi-trained panelists. The results show that different ratios of nutmeg flesh juice and dragon fruit juice significantly influence the consumers' preference for color, appearance, taste, aroma, texture, and overall acceptance. The nutmeg-sheet jam with a proportion of $75 \%$ nutmeg juice and $25 \%$ of dragon juice was the most preferred product by the consumers. The selected product has $28.72 \mathrm{mg}$ vitamin $\mathrm{C} / 100 \mathrm{~g}$ of ingredients and $\mathrm{pH} 4.2$.
\end{abstract}

Keywords: nutmeg flesh, dragon fruit, nutmeg-sheet jam, consumers' preference

ABSTRAK

Pemanfaatan daging buah pala masih terbatas, sehingga pengolahan daging buah pala menjadi selai lembaran merupakan usaha untuk meningkatkan nilai guna. Namun, daging buah pala memiliki rasa sepat dan rasa getir yang disebabkan oleh adanya kadar tannin yang akan berdampak pada produk olahannya. Untuk mengatasi permasalahan ini, maka dilakukan kombinasikan daging buah pala dengan buah naga. Tujuan penelitian ini adalah menentukan proporsi sari buah pala dan sari buah naga yang tepat yang dapat menghasilkan selai lembaran yang disukai oleh konsumen. Penelitian ini menggunakan Rancangan Acak Lengkap satu faktor, yaitu proporsi sari buah pala dan sari buah naga yang terdiri dari tiga taraf perlakuan yaitu: $\mathrm{P}_{1}(100 \%: 0 \%), \mathrm{P}_{2}(75 \%: 25 \%), \mathrm{P}_{3}(50 \%: 50 \%)$. Pengujian organoleptik terhadap produk selai lembaran menggunakan uji hedonik oleh 30 panelis. Hasil penelitian menunjukkan bahwa rasio sari buah pala dan sari buah naga yang berbeda memberi pengaruh nyata terhadap tingkat kesukaan konsumen pada atribut warna/kenampakan, rasa, aroma, tekstur dan penerimaan keseluruhan (over all). Selai lembaran dengan penambahan rasio sari buah pala $75 \%$ dan sari buah naga $25 \%$ merupakan produk yang paling disukai oleh konsumen dengan kandungan vitamin C 28.72 $\mathrm{mg} / 100 \mathrm{~g}$ bahan dan $\mathrm{pH} 4.2$.

Kata kunci : daging buah pala, buah naga, selai lembaran, preferensi konsumen 


\section{PENDAHULUAN}

Seiring dengan pertumbuhan ekonomi di kawasan Asia, khususnya di Indonesia, pola kehidupan masyarakat modern telah banyak berubah, menuntut segala sesuatu yang serba praktis termasuk konsumsi dan pengolahan makanan. Sarapan dengan sekerat roti yang dilengkapi selai merupakan pola hidup yang biasa, hal ini mengakibatkan permintaan terhadap roti terus meningkat yang secara tidak langsung juga meningkatkan permintaan terhadap selai sebagai makanan olahan pendamping roti (Ramadhan \& Trilaksani, 2017).

Selai adalah salah satu jenis makanan awetan berupa sari buah atau buah-buahan yang sudah dihancurkan, ditambah gula dan dimasak hingga kental. Selai yang beredar di pasaran umumnya berbentuk selai oles, hal ini dianggap kurang praktis karena penyajiannya, sehingga perlu pengembangan bentuk olahan lain sebagai contoh selai lembaran (Natan et al., 2019). Selai lembaran merupakan hasil modifikasi dari selai yang semi padat. Lembaran tipis dari selai lembaran menyerupai lembaran keju (cheese slices). Selai lembaran bermutu baik apabila tekstur lembut, konsisten, mempunyai flavor dan warna buah alami. Selain itu, selai lembaran yang baik juga dicirikan dengan dapat diangkatnya keseluruhan selai lembaran tanpa patah dan juga dapat digulung, serta teksturnya tidak mudah sobek (Yenrina et al., 2009).

Banyak buah-buahan yang sudah dieksplorasi sebagai bahan baku selai lembaran antara lain: nenas, buah naga, pisang, jambu, belimbing, terong belanda, papaya, semangka, markisa, tomat, mangga, labu kuning dan buah lainnya. Buah yang belum banyak diolah salah satunya daging buah pala.Dalam $100 \mathrm{~g}$ daging buah pala terkandung kalori $42 \mathrm{Kal}$, protein $0,3 \%$, lemak 0,2 \%, pati 10,9\%, vitamin A 29,5 UI, vitamin C $22 \mathrm{mg}$, kalsium $32 \mathrm{mg}$, fosfor $24 \mathrm{mg}$, zat besi 1,5 mg, minyak atsiri 1,1\% (Rismunandar, 1990). Daging buah pala mengandung minyak atsiri dengan senyawa kimia utama antara lain a-pinene (14,2\%), a-terpineol $(13,6 \%)$, myristicin (13.1\%), terpinene-4-ol (12,4\%), limonene (10,9\%), $\beta$-pinene $(8.2 \%)$, a-terpinolene $(7,5 \%), \delta$-terpinene $(7,3 \%)$ (Sipahelut et al., 2019). Adanya kandungan senyawa-senyawa kimia ini bermanfaat bagi kesehatan, diantaranya dapat mengobati masuk angin, insomnia, memperlancar pencernaan dan meningkatkan selera makan, memperlancar buang angin (Nurdjanah, 2007).

Pemanfaatan daging buah pala masih terbatas, sehingga biasanya terbuang percuma dan menjadi limbah. Pengolahan daging buah pala menjadi selai lembaran merupakan salah satu usaha untuk meningkatkan nilai guna. Daging buah pala yang pada awalnya kurang memiliki nilai ekonomi setelah diolah menjadi produk pangan olahan akan memiliki nilai ekonomi yang tinggi (Karseno \& Setyawati, 2013). Aroma pala yang sangat khas berpotensi untuk diolah menjadi selai lembaran. Namun, permasalahan yang dihadapi dalam mengolah daging buah pala adalah daging buah pala memiliki rasa sepat dan rasa getir yang disebabkan oleh adanya 
kadar tannin yang akan berdampak pada produk olahannya. Kandungan tannin pada daging buah pala berkisar 12.34 \%-15.30 \% (Fidriany et al., 2004). Penelitian Ermiati dan Sumangat (1993) dalam Suhirman et al. (2006) menunjukkan bahwa preferensi konsumen terhadap sari buah pala yang disimpan, diketahui bahwa hasil uji organoleptik terhadap cita rasa sari buah pala berada pada kisaran agak suka. Untuk mengatasi permasalahan ini, maka perlu mengkombinasikan daging buah pala dengan buah lain, diantaranya buah naga.

Setiap $100 \mathrm{~g}$ buah naga mengandung 82.5-83 g air, 0.21-0.61 g lemak, 1.15-0.22 g protein, 0.7-0.9 g serat, 0.005-0.01 mg karoten, 6.3-8.8 mg kalsium, 30.2-31.6 mg fosfor, 0.55-0.65 mg besi, 13-18 briks kadar gula, 11.5 g karbohidrat, 60.4 mg magnesium serta vitamin B1, B2 dan vitamin C (Cahyono, 2009; Kristanto, 2009 dalam Susanti \& Sampepana, 2017), mempunyai kandungan zat bioaktif yang bermanfaat bagi tubuh diantaranya antioksidan (asam askorbat, betakaroten, dan antosianin), pigmen betalain dan mengandung serat pangan dalam bentuk pektin. Buah naga memiliki khasiat untuk kesehatan manusia, antara lain sebagai penyeimbang gula darah, pencegah kanker usus, pelindung kesehatan mulut, pengurang kolesterol, pencegah pendarahan, dan obat keluhan keputihan (Huriah et al., 2019).

Penambahan buah naga dalam pembuatan selai lembaran pala harus tepat agar dapat menghasilkan selai lembaran yang bermutu baik, terutama teksturnya yang lembut dan konsisten. Proporsi penggunaan buah naga yang terlalu tinggi dapat menyebabkan aroma pala tidak terasa dan apabila penggunaan buah naga yang terlalu rendah menyebabkan produk selai lembar memiliki rasa getir dan sepat yang kuat. Dengan demikian, tujuan dari penelitian ini adalah menentukan proporsi daging buah pala dan buah naga yang tepat yang dapat menghasilkan selai lembaran pala yang disukai oleh konsumen.

\section{BAHAN DAN METODE}

\section{Bahan}

Bahan-bahan yang digunakan pada penelitian ini adalah daging buah pala, daging buah naga, agar-agar tepung, gula pasir, asam sitrat, margarin. Bahan kimia yang digunakan adalah indikator kanji (teknis), larutan iod 0,01 N (teknis).

\section{Tahapan Penelitian}

\section{Pembuatan Sari Buah Pala}

Daging buah pala disortasi dan dikupas kulitnya.Setelah itu direndam dalam larutan garam selama 10 menit. Kemudian daging buah pala dicuci dan di-blanching selama 5 menit. Selanjutnya dihancurkan menggunakan blender dengan penambahan air $1: 1$. Setelah itu, disaring menggunakan kain saring. 


\section{Pembuatan Sari Buah Naga}

Buah naga merah dicuci dan dihilangkan sisik-sisik kulit buahnya dan dipisahkan antara daging dengan kulit buah naga merah. Kemudian dilakukan pemotongan atau pengecilan ukuran untuk mempermudah proses penghancuran. Kemudian dihancurkan dengan blender dan ditambahkan air dengan perbandingan 1:1.Setelah itu, disaring menggunakan kain saring.

\section{Pembuatan Selai Lembaran}

Sari buah pala dan sari buah naga ditimbang dengan perbandingan (100:0, 75:25, 50:50). Campuran ditambahkan gula 50\%, agar-agar tepung 1\%, asam sitrat 0,04\%, margarin $4 \%$ dan dimasak selama 30 menit sampai membentuk gel. Gel yang terbentuk kemudian dicetak pada loyang ukuran $10 \times 10 \mathrm{~cm}$.

\section{Vitamin C}

Penentuan Vitamin C menggunakan metode Titrasi lodimetri (AOAC,1995). Sampel yang dihancurkan, ditimbang sebanyak 5 gram. Kemudian dilarutkan pada labu $100 \mathrm{~mL}$ dan ditanda bataskan. Larutan tersebut disaring dan filtratnya dipipet sebanyak $25 \mathrm{~mL}$. Ditambahkan beberapa tetes indikator kanji, lalu dititrasi dengan cepat menggunakan larutan iod 0,01 $\mathrm{N}$ hingga warna biru. Kandungan vitamin $\mathrm{C}$ dihitung dengan rumus :

Vit C $(\mathrm{mg} / 100 \mathrm{~g})=\underline{\left(\mathrm{VI}_{2} \times 0.88 \times \mathrm{fp}\right) \times 100}$

W s (gram)

$\mathrm{VI}_{2}=$ Volume lodium $(\mathrm{mL})$

$0.88=0.88 \mathrm{mg}$ asam askorbat

\section{Penilain Organoleptik}

Uji organoleptik dilakukan untuk mengetahui preferensi konsumen terhadap produk yang dihasilkan berdasarkan kriteria warna, rasa, aroma, tekstur dan penerimaan secara keseluruhan. Pengujian organoleptik terhadap produk selai lembaran pala dilakukan menggunakan uji hedonik yang bertujuan untuk mengevaluasi kesukaan panelis terhadap selai lembaran pala yang dihasilkan. Uji ini dilakukan oleh 30 panelis semi terlatih. Panelis semi terlatih adalah panelis yang sebelumnya telah diberi penjelasan tentang sifat-sifat tertentu dari produk yang akan diuji, dipilih dari kalangan terbatas serta data hasil pengujian diolah terlebih dahulu sehingga data yang sangat menyimpang tidak akan digunakan (Kailaku et al., 2016). Skala yang digunakan adalah skala kategori 6 poin dengan deskripsi sebagai berikut (1) Sangat tidak suka, (2) Tidak suka, (3) Agak tidak suka, (4) Agak suka, (5) Suka, (6) Sangat suka. 


\section{Rancangan Penelitian}

Penelitian ini menggunakan Rancangan Acak Lengkap satu faktor, yaitu proporsi sari buah pala dan sari buah naga yang dilambangkan dengan huruf $(P)$ yang terdiri dari tiga taraf perlakuan yaitu: $P_{1}$ : rasio sari buah pala dan sari buah naga $100: 0, P_{2}$ : rasio sari buah pala dan sari buah naga $75: 25$; $P_{3}$ : rasio sari buah pala dan sari buah naga $50: 50$.

\section{Analisis Data}

Data yang diperoleh dianalisis dengan metode One Way Analysis of Variance (ANOVA) menggunakan software SPSS versi 17. Hasil analisis terdapat pengaruh oleh perlakuan, dilanjutkan dengan Duncan's Multiple Range Test (DMRT) pada taraf signifikansi $a=0.05$.

\section{HASIL DAN PEMBAHASAN}

\section{Vitamin C}

Buah-buahan mengandung berbagai macam vitamin, salah satunya adalah vitamin $\mathrm{C}$. Vitamin $\mathrm{C}$ diperlukan oleh tubuh agar tubuh dapat melakukan proses metabolisme dan pertumbuhan yang normal, vitamin $\mathrm{C}$ juga dapat berperan sebagai antioksidan yang merupakan satu mekanisme pertahanan yang paling penting untuk melawan radikal bebas (Suhaera et al., 2019). Hasil uji vitamin C selai lembaran dengan proporsi sari buah pala dan sari buah naga yang berbeda dapat dilihat pada Gambar 1.

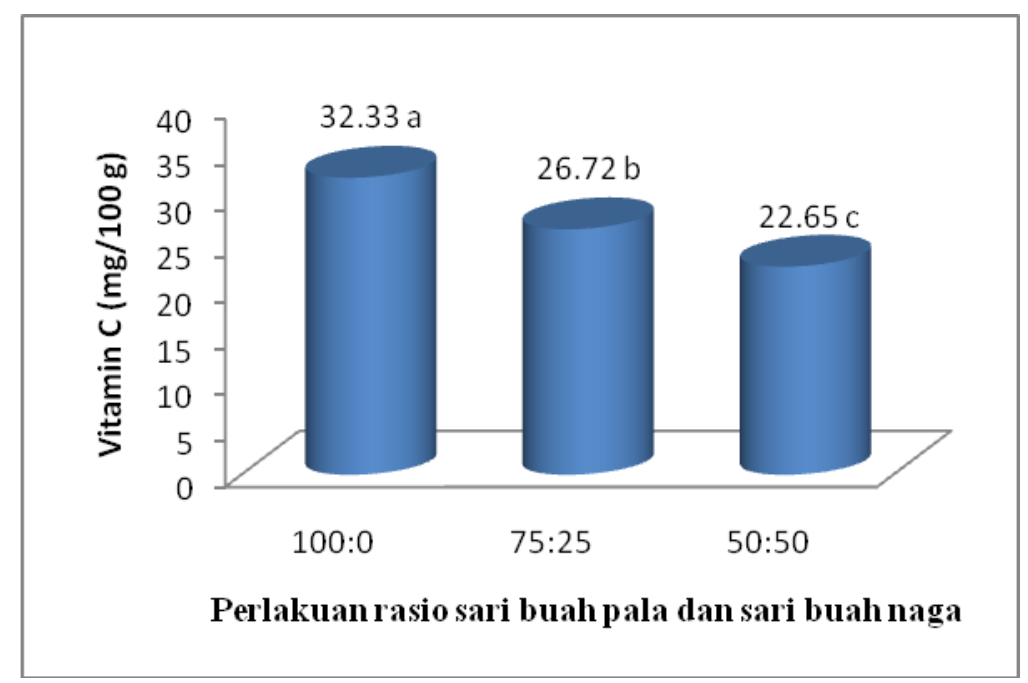

Gambar 1. Pengaruh perlakuan rasio sari buah pala dan sari buah naga terhadap vitamin $\mathrm{C}$ selai lembaran

Kadar vitamin C selai lembaran yang dihasilkan dalam penelitian ini berkisar antara 22.65 - $32.33 \mathrm{mg} / 100$ g. Berdasarkan hasil analisis sidik ragam, rasio sari buah pala dan sari buah naga berpengaruh nyata terhadap 
vitamin C selai lembaran pala. Penggunaan sari buah pala yang semakin banyak pada selai lembaran pala ini berkontribusi terhadap peningkatan vitamin $\mathrm{C}$. Nilai vitamin $\mathrm{C}$ selai lembaran yang paling tinggi pada perlakuan $P_{1}$ (rasio sari buah pala dan sari buah naga $100: 0$ ), sedangkan yang paling rendah pada perlakuan $P_{3}$ (rasio sari buah pala dan sari buah naga $50: 50$ ). Hal ini disebabkan karena daging buah pala memiliki kandungan vitamin $\mathrm{C}$ yang lebih tinggi dari daging buah naga. Kadar vitamin $\mathrm{C}$ daging buah pala sebesar 22,00 mg/100 g (Mandel, 2014), sedangkan kadar vitamin C daging buah naga merah 5.28 mg/100 gr (Risnayanti et al., 2015).

Kebutuhan vitamin $\mathrm{C}$ bagi orang dewasa adalah sekitar $60 \mathrm{mg}$, untuk wanita hamil $95 \mathrm{mg}$,anak-anak 45 mg, dan bayi $35 \mathrm{mg}$. Namun karena banyaknya polusi di lingkungan antara lain adanya asap kendaraan bermotor dan asap rokok, maka penggunaan vitamin C perlu ditingkatkan hingga dua kali lipatnya yaitu 120 mg (Putra, 2011 dalam Suhaera et al., 2019).

\section{Derajat Keasaman (pH)}

Asam berfungsi untuk membantu terbentuknya sifat koloidal dari larutan selai, sehingga lembaran terbentuk dengan baik. Hasil uji pH selai lembaran dengan proporsi sari buah pala dan sari buah naga yang berbeda dapat dilihat pada Gambar 2.

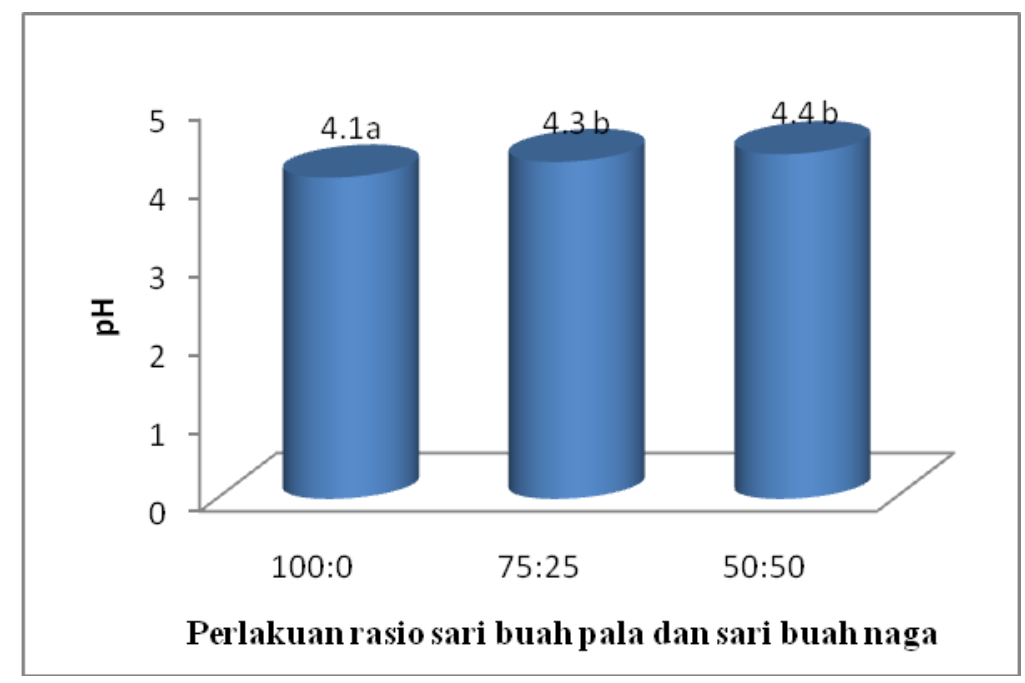

Gambar 2. Pengaruh perlakuan rasio sari buah pala dan sari buah naga terhadap pH selai lembaran

pH selai lembaran yang dihasilkan dalam penelitian ini berkisar antara 4.1 - 4.4. Berdasarkan hasil analisis sidik ragam, rasio sari buah pala dan sari buah naga berpengaruh nyata terhadap pH selai lembaran pala. Berdasarkan hasil pengukuran nilai pH terlihat bahwa perlakuan $\mathrm{P}_{1}$ (rasio sari buah pala dan sari buah naga 100 : 0) memiliki $\mathrm{pH}$ terendah, sedangkan yang tinggi pada perlakuan $\mathrm{P}_{3}$ (rasio sari buah pala dan sari buah naga 75 : 
25). Semakin tinggi jumlah sari buah pala yang ditambahkan, nilai pH semakin menurun. Hal ini disebabkan karena jumlah asam dalam hal ini asam organik yang ada pada sari pala semakin banyak. Semakin tinggi jumlah asam, semakin tinggi $\mathrm{pH}$.

pH yang dikehendaki dalam pembuatan selai sebesar 3.10-3,46 dan pH standar selai 3.5-4.5 (FDA, 2007 dalam Febriani et al., 2017). Menurut Ramadhan \& Trilaksani, (2017), derajat keasaman (pH) 3-4 mampu mengendalikan dan menjaga kestabilan pertumbuhan mikroorganisme produk karena kondisi selai dengan $\mathrm{pH}$ terlalu rendah atau terlalu asam dapat menyebabkan keluarnya air dari gel (sineresis) dan menyebabkan ketidakstabilan pada gel selai.

\section{Kesukaan Warna/Penampakan}

Penampakan produk merupakan atribut yang paling penting pada suatu produk. Dalam memilih sebuah produk, konsumen akan mempertimbangkan kenampakan dari produk tersebut terlebih dahulu dan mengesampingkan atribut sensori lainnya. Hal tersebut dikarenakan penampakan dari suatu produk yang baik cenderung akan dianggap memiliki rasa yang enak dan memiliki kualitas yang tinggi. Karakteristik dari kenampakan umum produk meliputi warna, ukuran, bentuk, tekstur permukaan, tingkat kemurnian dan karbonasi produk. Pada komoditi pangan, warna mempunyai peranan yang penting sebagai daya tarik, tanda pengenal, dan atribut mutu. Warna merupakan faktor mutu yang paling menarik perhatian konsumen, warna memberikan kesan apakah makanan tersebut akan disukai atau tidak (Mandei \& Nuryadi, 2019). Warna suatu bahan pangan dipengaruhi oleh cahaya yang diserap dan dipantulkan dari bahan itu sendiri dan juga ditentukan oleh faktor dimensi yaitu warna produk, kecerahan, dan kejelasan warna produk (Rahayu, 2011 dalam Ellora et al., 2018). Hasil uji kesukaan terhadap warna selai lembaran pala dapat dilihat pada Gambar 3.

Hasil uji organoleptik terhadap hedonik warna/kenampakan selai lembaran pala diperoleh bahwa nilai rata-rata warna selai lembaran berkisar antara 3.45 - 5.60 yang secara deskriptif berkisar antara skala agak tidak suka menuju sangat suka (Gambar 3). Berdasarkan hasil analisis sidik ragam, rasio sari buah pala dan sari buah naga berpengaruh nyata terhadap warna/kenampakan selai lembaran pala. Penambahan sari buah naga yang semakin banyak pada selai lembaran pala ini berkontribusi terhadap warna yang lebih disukai. Nilai kesukaan panelis terhadap warna selai lembaran yang paling rendah pada perlakuan $\mathrm{P}_{1}$ (rasio sari buah pala dan sari buah naga $100: 0$ ), sedangkan yang paling tinggi pada perlakuan $P_{2}$ (rasio sari buah pala dan sari buah naga $75: 25$ ). Pada penggunaan sari buah pala 100\%, selai lembaran pala yang dihasilkan memiliki warna kuning kecoklatan, sesuai dengan warna sari buah pala. 


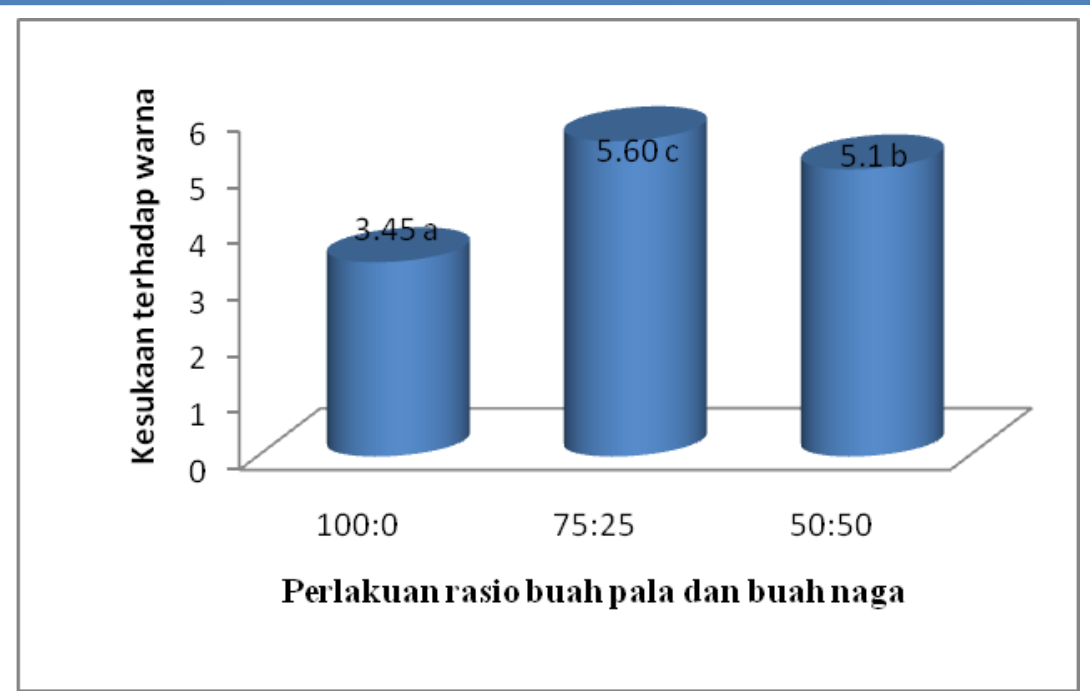

Gambar 3. Hasil uji kesukaan terhadap warna selai lembaran pala

Adanya penambahan sari buah naga menyebabkan warna selai lembaran mengalami perubahan, dimana pigmen warna merah buah naga sangat dominan dibandingkan daging buah pala. Buah naga mengandung antosianin 28,7 - 55,6 mg/100 g (Vargas et al., 2013) yang berwarna merah. Semakin tinggi penambahan sari buah naga akan menghasilkan selai lembaran yang lebih disukai oleh panelis. Meskipun demikian, jika penambahan sari buah naga terlalu banyak, akan memberikan selai lembaran dengan warna merah gelap yang menurunkan kesukaan panelis. Menurut Winarno (1997) dalam Rosiani et al. (2015), warna pada bahan dapat berasal dari pigmen alami bahan pangan itu sendiri, reaksi karamelisasi, reaksi Maillard, reaksi senyawa organik dengan udara, dan penambahan zat warna, baik alami maupun sintetis.

\section{Kesukaan Rasa}

Rasa merupakan faktor yang sangat penting dalam menentukan keputusan akhir konsumen untuk menerima atau menolak suatu makanan. Rasa sangat sulit dimengerti secara tuntas karena selera manusia sangat beragam. Meskipun parameter lain nilainya baik, jika rasa tidak enak atau tidak disukai, maka produk akan ditolak (Mutia \& Yunus, 2016). Rasa makanan merupakan gabungan dari rangsangan cicip, bau dan pengalaman yang banyak melibatkan lidah (Winarno, 2002 dalam Sipahelut et al., 2017). Menurut Bangun, (2004) dalam Wibowo et al. (2014) bahwa rasa dari suatu bahan berasal dari bahan pangan itu sendiri, namun jika telah mengalami atau mendapatkan perlakuan pengolahan, maka rasa tersebut akan dipengaruhi oleh bahan-bahan yang ditambahkan dalam pembuatannya yang menambahkan tingkat kesukaan konsumen. Hasil uji kesukaan panelis terhadap rasa selai lembaran pala dapat dilihat pada Gambar 4. 


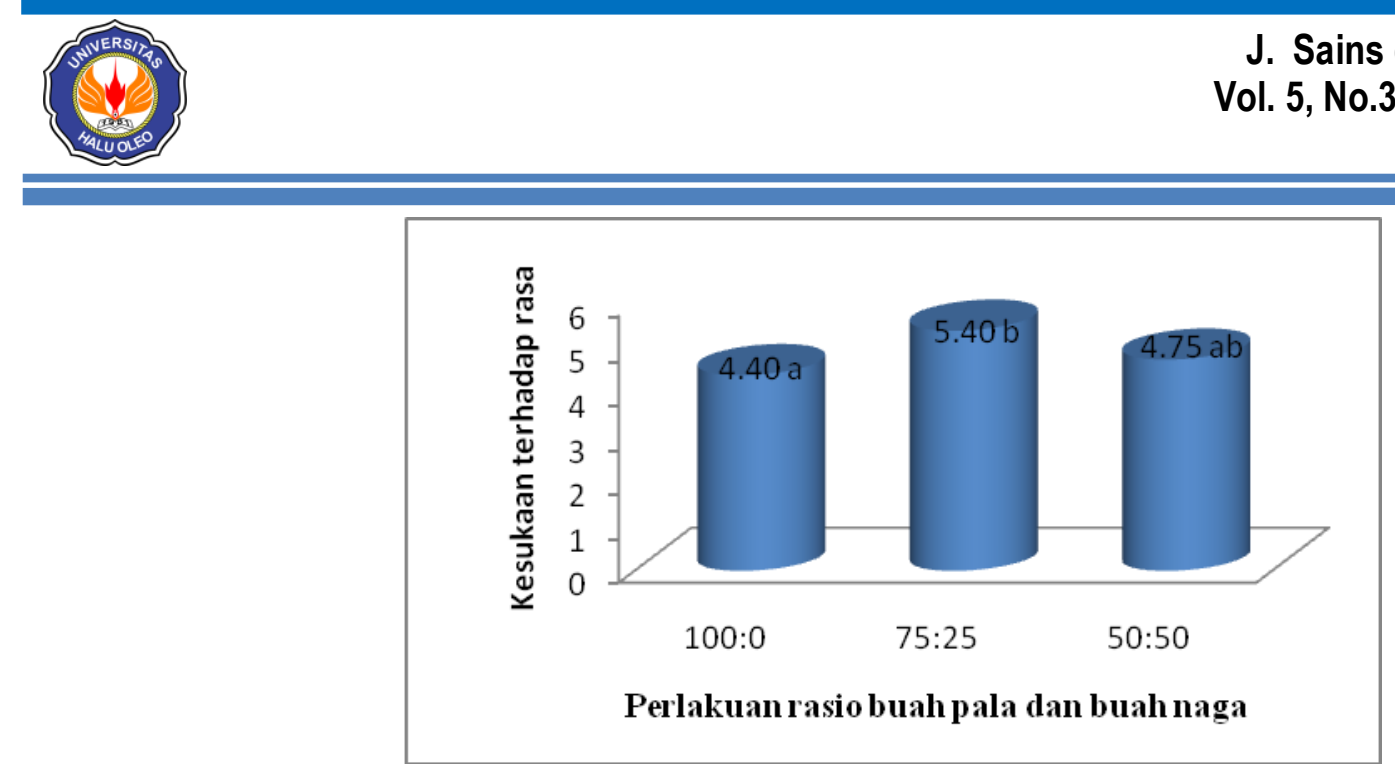

J. Sains dan Teknologi Pangan

Vol. 5, No.3, P. 2863-2877 Th 2020

Gambar 4. Hasil uji kesukaan panelis terhadap rasa selai lembaran pala

Hasil uji organoleptik terhadap hedonik rasa selai lembaran pala diperoleh bahwa nilai rata-rata rasa selai lembaran berkisar antara $4.40-5.40$ yang secara deskriptif berkisar antara skala agak suka sampai suka (Gambar 4). Berdasarkan hasil analisis sidik ragam, rasio sari buah pala dan sari buah naga berpengaruh nyata terhadap rasa selai lembaran. Nilai kesukaan panelis terhadap rasa selai lembaran yang paling rendah pada perlakuan $P_{1}$ (rasio sari buah pala dan buah naga $100: 0$ ), sedangkan yang paling tinggi pada perlakuan $P_{2}$ (rasio sari buah pala dan sari buah naga $75: 25$ ). Pada perlakuan $\mathrm{P}_{1}$, rata-rata panelis agak suka terhadap selai lembaran pala. Hal ini dikarenakan selai lembaran pala yang dihasillkan agak sepat dan getir. Dengan penambahan sari buah naga, rasa sepat dan getir dari pala berkurang.Namun, ketika penambahan buah naga semakin banyak, kesukaan panelis menjadi menurun karena rasa dan aroma pala semakin berkurang. Menurut Bumi et al., (2015), daging buah naga memiliki rasa yang lebih manis, lebih segar dan khas buah naga. Menurut Mc Bride dan Mac Fie (1990) dalam Agustina \& Handayani (2016), faktor yang mempengaruhi penerimaan panelis terhadap rasa adalah senyawa kimia, suhu, konsentrasi dan interaksi dengan komponen rasa yang lain. Produk yang memiliki rasa tidak enak tidak akan diterima oleh konsumen meski warna, aroma dan teksturnya baik.

\section{Kesukaan Aroma}

Aroma merupakan sensasi bau yang ditimbulkan oleh rangsangan kimia, senyawa volatil yang tercium oleh syaraf-syaraf olfaktori yang berada di rongga hidung ketika bahan pangan masuk ke mulut. Sensasi atau rangsangan tersebut senantiasa akan menimbulkan kelezatan, yang kemudian dapat mempengaruhi tingkat atau daya terima panelis atau konsumen terhadap suatu produk pangan tertentu (Winarno, 1997 dalam Handayani \& Aninah, 2011). Hasil uji kesukaan terhadap aroma selai lembaran pala dapat dilihat pada Gambar 5. 


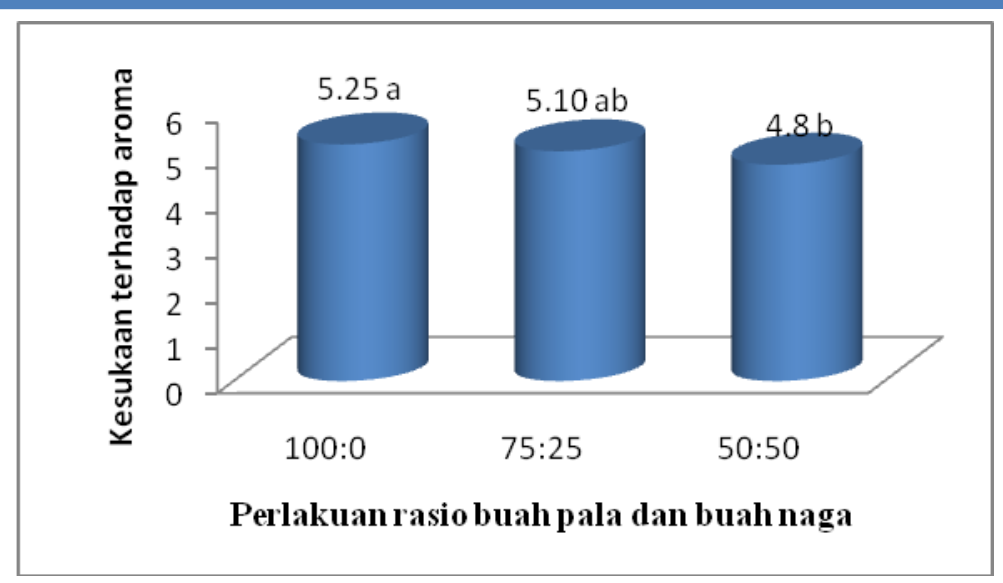

Gambar 5. Hasil uji kesukaan terhadap aroma selai lembaran pala

Hasil uji organoleptik terhadap hedonik aroma selai lembaran pala diperoleh bahwa nilai rata-rata aroma selai lembaran berkisar antara 4.80 - 5.25 yang secara deskriptif berada pada skala agak suka sampai suka (Gambar 5). Berdasarkan hasil analisis sidik ragam, perlakuan rasio sari buah pala dan sari buah naga berpengaruh nyata terhadap aroma selai lembaranpala. Penggunaan sari buah pala yang banyak memberikan aroma pala yang disukai konsumen. Daging buah pala mengandung minyak atsiri dengan komponen persenyawaan oksigenasi seperti linalool, terpinene-4-ol, a-terpineol yang banyak dibandingkan senyawa lain. Persenyawaan teroksigenasi merupakan penyebab utama bau wangi dalam minyak atsiri dan berpengaruh terhadap bau dan nilai flavor minyak (Sipahelut, S., 2013). Aroma buah naga tidak begitu kuat.Menurut Winarno (1991) dalam Karseno \& Setyawati (2013), bahwa dalam banyak hal, kelezatan makanan ditentukan oleh aroma makanan.Semakin tinggi proporsi sari buah naga, aroma pala semakin menurun. Hal ini disebabkan semakin banyak sari buah naga dan semakin berkurang sari buah pala yang ditambahkan akan menutupi aroma pala pada selai lembaran yang dihasilkan.

\section{Kesukaan Tekstur}

Tekstur suatu bahan pangan merupakan salah satu sifat fisik dari bahan pangan yang penting.Hal ini berhubungan dengan rasa pada waktu mengunyah bahan pangan tersebut. Salah satu cara penentuan tekstur suatu bahan adalah dengan memberikan beban terhadap bahan tersebut misalnya dengan pemeriksaan bekas atau tekanan jari (Mutia \& Yunus, 2016). Hasil uji kesukaan terhadap tekstur selai lembaran pala dapat dilihat pada Gambar 6. 


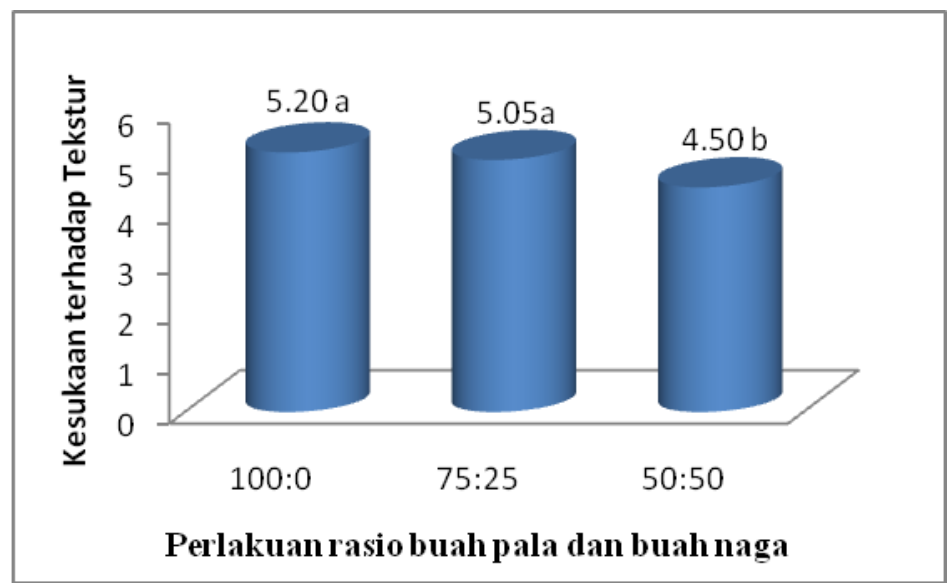

Gambar 6. Hasil uji kesukaan terhadap tekstur selai lembaran pala

Hasil uji organoleptik terhadap hedonik teksur selai lembaran paladiperoleh bahwa nilai rata-rata rasa selai lembaran berkisar antara 4.50 - 5.20 yang secara deskriptif berkisar antara skala agak suka sampai suka (Gambar 6). Berdasarkan hasil analisis sidik ragam, rasio sari buah pala dan sari buah naga berpengaruh nyata terhadap tekstur selai lembaran pala. Semakin banyak penggunaan sari buah pala, kesukaan panelis terhadap tekstur selai lembaran semakin meningkat. Selai lembaran dengan rasio sari buah pala yang tinggi lebih kokoh, tidak mudah patah/pecah. Hal ini diduga karena kandungan pektin dari daging buah pala lebih tinggi dibandingkan dengan buah naga. Pektin adalah campuran polisakarida kompleks (selulosa, hemiselulosa, pektin dan lignin) yang terdapat dalam berbagai buah dan sayur yang berfungsi sebagai pembentuk gel, perekat dan pengikat serta pembentuk tekstur (Bumi et al., 2015). Daging buah pala mengandung pektin yang tinggi yakni sebesar 7,36 \% bb, bila dibandingkan dengan buah naga.

Tekstur merupakan salah satu komponen terpenting yang menentukan kualitas akhir selai. Dalam pembuatan selai, komponen penting yang diperlukan untuk pembentukan gel ialah pektin, gula dan asam. Biasanya gel atau bentuk kental pada selai terjadi karena adanya reaksi dari pektin yang berasal dari buah dengan gula dan asam (Dewi et al., 2010). Pektin sangat penting dalam pembentukan selai karena berfungsi sebagai pembentuk kekentalan. Menurut Yuliani (2011), pektin mempunyai sifat yang dapat membentuk gel. Semakin banyak pektin, makin keras gel yang terbentuk.

\section{Penerimaan keseluruhan (over all)}

Kesukaan seseorang terhadap suatu produk dipengaruhi oleh beberapa faktor antara lain : (1) warna, rasa, dan penampilan yang menarik (sensori); (2) bernilai gizi tinggi (nutritional); dan (3) menguntungkan bagi tubuh konsumen (Nursalim \& Razali, 2007) dalam Purbasari et al., 2014). Atribut penerimaan keseluruhan (over 
all) yang dinilai panelis meliputi aspek warna, rasa, aroma, teksur dan lain-lain. Hasil uji kesukaan terhadap penerimaan keseluruhan selai lembaran pala dapat dilihat pada Gambar 7.

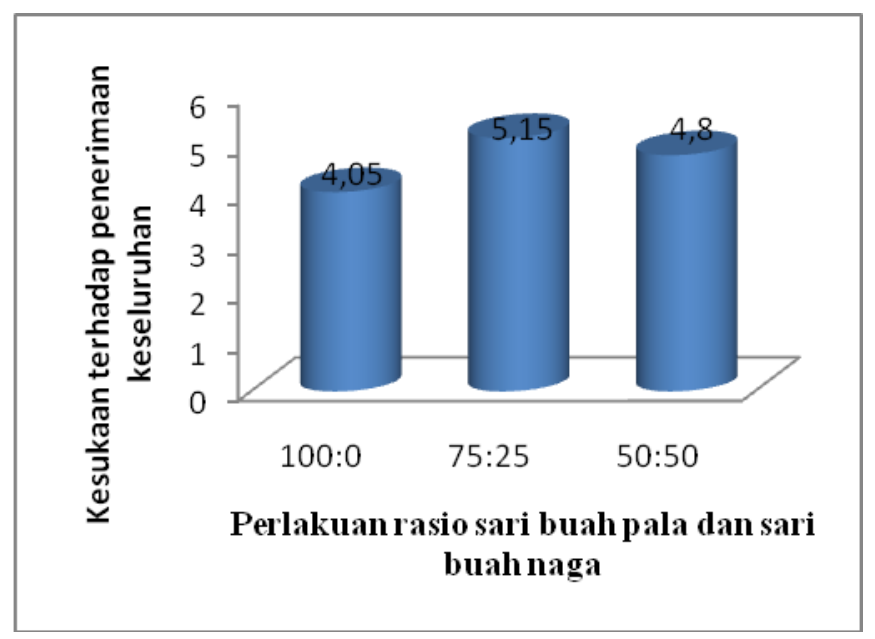

Gambar 7. Hasil uji kesukaan terhadap penerimaan keseluruhan selai lembaran pala

Hasil uji organoleptik terhadap hedonik penerimaan keseluruhan selai lembaran pala diperoleh bahwa nilai rata-rata penerimaan keseluruhan selai lembaran berkisar antara 4.05 - 5.15 yang secara deskriptif berkisar antara skala agak suka sampai suka (Gambar 7). Berdasarkan hasil analisis sidik ragam, rasio sari buah pala dan sari buah naga berpengaruh nyata terhadap penerimaan keseluruhan selai lembaran pala. Secara keseluruhan, panelis lebih menyukai selai lembaran pala dengan rasio sari buah pala dan sari buah naga $75 \%: 25 \%$. Hal ini dikarenakan aroma pala masih terasa, rasa sepat berkurang dan warna selai menarik, serta tekstur yang tidak patah.

\section{KESIMPULAN}

Berdasarkan hasil penelitian ini, maka disimpulkan bahwa bahwa rasio sari buah pala dan sari buah naga yang berbeda memberi pengaruh nyata terhadap tingkat kesukaan konsumen pada atribut warna/kenampakan, rasa, aroma, tekstur dan penerimaan keseluruhan (over all). Selai lembaran dengan penggunaan sari buah pala $75 \%$ dan sari buah naga $25 \%$ merupakan produk yang paling disukai oleh konsumen dengan kandungan vitamin C $28.72 \mathrm{mg} / 100 \mathrm{~g}$ bahan dan $\mathrm{pH} 4.2$. 


\section{DAFTAR PUSTAKA}

Agustina, W. W \& Handayani, M. N., 2016. Pengaruh Penambahan Wortel (Daucus carota) Terhadap Karakteristik Sensori dan Fisiko Kimia Selai Buah Naga Merah (Hyloreceus polyhiruz). Fortech 1 (1) : 1628.

Bumi, D. S, Yuwanti, S, Choiron, M., 2015. Karaktersitik Selai Lembar Buah Naga Merah (Hyloreceus polyhiruz) dengan Variasi Rasio Daging dan Kulit Buah. Berkalan Ilmiah Pertanian1 (5) : 90-98.

Dewi E. N., M. Surti,dan Ulfatun. 2010. Kualitas Selai Yang Diolah Dari Rumput Laut,Gracilaria Verrucosa, Eucheuma Cottonii, Serta Campuran Keduanya. (J. Fish. Sci.) XII (1): 20-27.

Edam, M., Suryanto E, Djarkasi, G.S.S., 2016. Karakteristik Kimia dan Aktivitas Antioksidan Minuman Instan Lemon Kalamansi (Citrus microcarpa) Dengan Penambahan Sari Daun Cengkeh (Eugenia carryophyllus) dan Daging Pala (Myristica fragrans). Jurnal Ilmu dan Teknologi pangan, 4 (1) : 1-8.

Handayani R \& Aminah S., 2011. Variasi Substitusi Rumput Laut Terhadap Kadar Serat dan Mutu Organoleptik Cake Rumput Laut (Eucheuma cottoni). Jurnal Pangan dan Gizi Vol 2 (3): 67-74.

Huriah, H., Alam, N, Noer, A.H., 2019. Karakteristik Fisik, Kimia dan Organoleptik Selai pada Berbagai Rasio Buah Naga Merah (Hylocereus polyrhizus Britt and Rose) - Gula Pasir. Jurnal Pengolahan Pangan, 4 (1) : 16-25.

Kailaku, S.I., Setiawan, B., Sulaeman, A. 2016. Pengaruh Proses Membran Ultrafiltrasi dan Ultraviolet Terhadap Komposisi Gizi, Sifat Fisikokimia dan Organoleptik Minuman Air Kelapa. Jurnal Littri 22 (1) : 43-51.

Karseno \& Setyawati, R., 2013. Karakteristik Selai Buah Pala : Pengaruh Proporsi Gula Pasir, Gula Kelapa, dan Nenas. Jurnal Pembangunan Pedesaan 13 (2): 147-148.

Mandei, J. H., 2014. Komposisi Beberapa Senyawa Gula Dalam Pembuatan Permen Keras dari Buah Pala. Jurnal Penelitian Teknologi Industri, 6 (1): 1-10.

Mandei, J. H., \& Nuryadi, A.M., 2019. Pengaruh pH Sari Buah Pala Terhadap Kandungan Gula Reduksi dan Tekstur Permen Keras. Jurnal Penelitian Teknologi Industri. 11 (1): 19-30.

Mutia, A. K., \& Yunus R., 2016. Pengaruh Penambahan Sukrosa pada Pembuatan Selai Langsat. Jtech, 4 (2) : $80-84$.

Natan, F.,Emmawati, A., Marwati, 2019. Pengaruh Formulasi Bubur Kolang-Kaling, Sari Buah Naga Super Merah dan Agar-Agar Terhadap Sifat Fisiko-Kimia dan Sensoris Selai lembaran. Journal of Tropical Agrifood, 1 (1): $9-18$.

Nisa S. R., Santoso, H., Syauqi, A., 2020. Analisis Kadar Vitamin C pada Selai Stroberi (Fragaria sp)-Buah Naga (Hylocereus costaricensis). Jurnal Ilmiah Sains Alami, 2 (2): 1-7. 
Nurdjanah N., 2007. Teknologi Pengolahan Pala. Badan Penelitian dan Pengembangan Pertanian. Bogor.

Ong, N. E., Djarkasi, G. S. S., Moningka, J. C. S., 2016. Tingkat Penerimaan Konsumen Terhadap Minuman Herbal Teh daun Sirsak (Annona muricata Linn.). Jurnal Cocos, 7 (3) : 1-5.

Purbasari A., Pramono, Y.B, S.B.M. Abduh. 2014. Nilai pH, Kekentalan, Citarasa Asam, dan Kesukaan Pada Susu Fermentasi Dengan Perisa Alami Jambu Air (Syzygium sp). Jurnal Aplikasi Teknologi Pangan 3 (4) : 174-177.

Ramadhan, W., \& Trilaksani, W., 2017. Formulasi Hidrokoloid-Agar, Sukrosa dan Acidulant pada Pengembangan Produk Selai Lembaran. JPHPI 20 (1) : 95-108.

Rismunandar. 1990. Budidaya dan Tata Niaga Pala. Cetakan kedua. Penebar Swadaya. Jakarta.

Rosiani, N., Basito, Widowati, E., 2015. Kajian Karakteristik Sensoris Fisik dan Kimia Kerupuk Fortifikasi Daging Lidah Buaya (Aloe vera) dengan Metode Pemanggangan Menggunakan Microwave. Jurnal Teknologi Hasil Pertanian 8 (2) : 84-98.

Sipahelut, S.G., 2013. Variasi Komposisi Kimia Minyak Atsiri dari Daging Buah Pala Melalui Beberapa Metode Pengeringan. Jurnal Agroqua 11 (1) : 29-32.

Sipahelut, S. G., Patty, Tetelepta, G., Patty, J. A., 2017. Kajian Penambahan Minyak Atsiri dari Daging Buah Pala (Myristica fragrans Houtt) Pada Cake Terhadap Daya Terima Konsumen. Jurnal Sains dan Teknologi Pangan 2 (2) : 486-495.

Sipahelut, S. G., Patty, J. A, Patty, Z., Kastanja, A. Y, Lekahena, V. N. J., 2019. The Antibacterial and Antifungal Activity of Essential Oil Derived From The Flesh of Nutmeg Fruit. Eur Asian Journal of Bio Sciences 13 (2): 93-98.

Sipahelut, S. G., Kastanja, A. Y., Patty, Z., 2020. Antioxidant Activity of Nutmeg Fruit Flesh-Derived Essential Oil Obtained Through Multiple Drying Methods. Eur Asian Journal of BioSciences 14 (1) : 21-26.

Suhirman, S., Hadad, E. S, Lince, 2006. Pengaruh Penghilang Tanin dari Jenis Pala Terhadap Sari Buah Pala. Buletin Littro, 17 (1) : 39-52.

Susanty, A dan Sampepana, E., 2017. Pengaruh Masa Simpan Buah Terhadap Kualitas Sari Buah Naga Merah (Hylocereus polyrhizus). Jurnal Riset Teknologi Industri 11 (2) : 76-82.

Utami, S., Zuprizal, Supadmo, 2012. Pengaruh Penggunaan Daging Buah Pala Dalam Pakan (Myristica fragrans Houtt) Terhadap Kinerja Ayam Broiler Pada Kepadatan Kandang yang Berbeda. Buletin Peternakan 36 (1) : 5-13.

Vargas, M.L., Cortez, J.A.T., Duch, E.S., Lizama1, A.P. \& Méndez, C.H.H. 2013. Extraction and Stability of Anthocyanins Present in the Skin of the Dragon Fruit (Hylocereus undatus). Food and Nutrition Sciences, 4 : 1221-1228. 
Wibowo R. A, Nurainy F, Sugiharto R., 2014. Pengaruh Penambahan Sari Buah Tertentu Terhadap Karakteristik Fisik, Kimia, dan Sensori Sari Tomat. Jurnal Teknologi Industri dan Hasil Pertanian 19 (1) : 11-27.

Yenrina, R., Hamzah, N., Zilvia, R., 2009. Mutu Selai Lembarn Campuran Nenas (Ananas comusus) dengan Jonjot Labu Kuning (Cucurbita moschata). Jurnal Pendidikan dan keluarga 1 (2) : 33-42.

Yuliani H.R. 2011. Karakterisasi Selai Tempurung Kelapa Muda. Prosiding Seminar Nasional Teknik Kimia "Kejuangan" Pengembangan Teknologi Kimia untuk Pengolahan Sumber Daya Alam Indonesia Yogyakarta, 22 Februari 2011. Jurusan Teknik Kimia, Politeknik Ujung Pandang. 